\title{
The Barriers of Adoption the E-Banking in the Libyan Banks-A Case Study of Commercial Banks in Tobruk City
}

\author{
Hussam Alnaas \\ University of Tobruk, Tobruk, Libya \\ Email: hussam.alnaas@tu.edu.ly
}

How to cite this paper: Alnaas, H. (2022). The Barriers of Adoption the E-Banking in the Libyan Banks-A Case Study of Commercial Banks in Tobruk City. Open Journal of Business and Management, 10, 501-524. https://doi.org/10.4236/ojbm.2022.101028

Received: December 10, 2021

Accepted: January 26, 2022

Published: January 29, 2022

Copyright ( 2022 by author(s) and Scientific Research Publishing Inc. This work is licensed under the Creative Commons Attribution International License (CC BY 4.0).

http://creativecommons.org/licenses/by/4.0/ (c) (i) Open Access

\begin{abstract}
The goal of this study is to identify the major barriers to E-Banking adoption at Libyan commercial (public and private) banks. According to the results, there are significant barriers to E-Banking adoption: (Electronic Barriers, Regulatory Barriers and Cultural Barriers). The study also found that there were no differences between the respondents' answers in the presence of these Barriers due to the Ownership of the Bank, where, almost all participants, whether from publicly or privately banks, seemed to agree on the Barriers to E-Banking Adoption. This research suggests that in order to effectively execute E-Banking in Libyan commercial banks, the following process needs to be taken, necessity Increasing staff of banks awareness of modern banking technologies. The government should create a favorable environment for this industry. It provides adequate education and technological support, and banks should build their own E-Banking strategic plans.
\end{abstract}

\section{Keywords}

E-Banking, Commercial Banks, Barriers, Tobruk, Libya

\section{Introduction}

Electronic banking has triggered massive change in the commercial banking practices since it was first introduced as "home banking" services by the four major New York banks in 1981 (Osho, 2008). Where the E-Banking industry has expanded rapidly over the course of time with the growth and widespread Internet, most businesses and industries have turned their business into online services to deliver e-commerce, easy access and communication to enable better efficiency and accessibility for their customers (Nuha, Mahmud, \& Sattar, 2021). 
This has made banks shift their focus on E-Banking (Chhaya \& Mittal, 2021), where Online banking (Internet banking) has emerged as one of the most profitable e-commerce applications over the last decade (Lee, 2009).

According to (Boshkoska \& Sotiroski, 2018), the level of E-Banking services implementation differs in different countries; it depends on the level of social economic and cultural development in the countries.

Electronic banking also known as online banking is a modern behavior practiced by consumers and sellers to engage in financial transactions through Internet platforms and through the mobile systems such as mobile payment applications (Mohammed \& Faleel, 2021). In the context of an information system, E-Banking is defined as an electronic payment system that customers can use to conduct their online financial transactions (Bouthahab \& Geador, 2014; Kimiagari \& Baei, 2021). Other authors define E-Banking as the use of the Internet to offer banking activities such as transferring funds, paying bills, monitoring the current account balance and savings, paying mortgages and purchasing financial instruments and certificates of deposit (Zyberi, 2021).

Furthermore, the major benefits of online banking services help banks to keep and enhance the loyalty of their obtainable customers, provide opportunity to the banks to increase market share, increase customer satisfaction, reduce operational and administrative cost and improve banks' competitive positions against their rivals (Hammouri, Majali, Almajali, Aloqool, \& AlGasawneh, 2021; Kimiagari \& Baei, 2021). The Internet itself however is not a secure medium and thus poses a number of risks of concern to regulators and supervisors of banks and financial institutions (Paliwal, 2017).

In Libya e-marketing and E-Banking are new approaches which banks need to accept according to banking changes in world market place (Ullah, Kamal, \& Ghani, 2013). Thus, some banks in Libya have received a lot of advises to launch electronic banking, They have recognized the benefits of electronic banking and believe that the acceptance of all aspects of electronic banking will drive towards competitive performance on the international stage and enhance efficiency, performance and service quality, (Abukhzam \& Lee, 2010). Its services have been launched by private commercial banks in Libya, the global private banks request improvement product to be automatically ready. In fact, Libyan banks have launched it and started to provide their customers a new innovation as automated teller machines (ATMs) and telephone banking. But they are still focusing on traditional banking process to undertake their routine banking actions. Even though electronic banking has found its way to Libyan bank sector but with very limited usage (Bouthahab \& Elmansori, 2017; Elgahwash, 2013; Mohamed, 2013).

Although the study of financial services has obtained increased attention over the last few years; there is still to pose challenges for academics and marketers alike (Hammouri et al., 2021; Rajguru, 2014), especially in North Africa (Azouzi, 2009), where, still limited empirical work simultaneously captures the success 
factors (positive factors) and resistance factors (negative factors) that help customers to adopt online banking (Kurnia, Peng, \& Liu, 2010; Lee, 2009). Thus (Tiong, 2020) hopes to close the gap of limitation by exploring the factors influencing consumer's intention to adopt a new technology.

Several studies (Chedrawi, Harb, \& Saleh, 2019; Daka \& Phiri, 2019; Hammoud, Bizri, \& El Baba, 2018; Keskar \& Pandey, 2018; Kurnia et al., 2010; Rahi, Ghani, \& Alnaser, 2017) have recommended the need to carry out more studies to find out the reality of electronic banking and what are the most important factors that contribute to the dissemination and development of electronic banking work. Therefore, a better understanding of the adoption of E-Banking particularly the barriers through an in-depth study of a Libyan Banks will enrich the existing knowledge in this area. (Abukhzam \& Lee, 2010), argue that A review of the literature on ICT usage finds that, in comparison to the developed world, there have been very few research on Technology adoption in developing nations, and even less studies on the Middle East, including Libya. As a result, it's critical to figure out what factors determinants of bank staffers' views regarding E-Banking implementation. The rest of the paper has organized as follows. Section 2 presents the literature review presents E-Banking, This part also presents hypotheses of study. Section 3 discusses methodology and followed by discussions of findings and conclusion. Section 4 presents research recommendation.

\section{Literature Review}

According to (Economic Commission for Africa, 2007), the growth of E-Banking in most African countries has been slow for a variety of reasons which include: low levels of internet penetration and poorly developed telecommunications infrastructures (especially beyond urban areas), unaware of the opportunities offered by E-Banking, lack of a suitable legal framework and security measures, inadequate banking systems and high rates of illiteracy.

Indeed, E-Banking represents the latest initiative in the range of innovative banking services such as Tele-Banking, ATM and electronic cards (Altobishi, Erboz, \& Podruzsik, 2018; Daniela, Simona, \& Dragos, 2010; Safeena, Date, \& Kammani, 2011), where several advantages related to the use of E-Banking compared to the traditional banking system are recorded. According to (Chedrawi et al., 2019), E-Banking services offer the banking sector several opportunities to meet the needs of existing customers and attract new potential clients; as a matter of fact, banks and their customers (individuals or companies) benefit from the use of alternative channels and electronic banking services, Furthermore, E-Banking is a term that encompasses the process by which a consumer can electronically manage his or her banking transactions without having to visit a physical branch. Moreover, E-Banking enables customers to manage their financial operations in a more flexible way on a $24 / 7$ basis instead of getting restricted by the timings of the physical branch. It is thus a self-service that elimi- 
nates time and space constraints in the performance of banking operations and ensures comfort and availability for customers (Hu \& Liao, 2011; Oni \& Ayo, 2010).

However, there are several major challenges and issues facing the E-Banking industry (Inegbedion et al., 2019; Kurnia et al., 2010; Yaseen \& El Qirem, 2018). Where still a large group of customers who refuse to adopt such services for multiple reasons for this (Arora \& Kaur, 2018; Lee, 2009; Oni \& Ayo, 2010), particularly in developing countries (Ismail \& Alawamleh, 2017), such as Libya (Abukhzam \& Lee, 2010). Where (Mohamed, 2013) argues that, the Libyan banking industry is now lagging behind and in extreme need of essential change to enhance its banking system, as it has been continuously criticized for its inadequate and inefficient services.

According to (Mathiyarasan \& Chitra, 2019) automated service is still at its infancy stage and there is no generally accepted theoretical conceptualization of automated service quality. Where, (Boshkoska \& Sotiroski, 2018), argue that in the developed economies the E-Banking implementation is on a very higher level compared to developing countries and underdeveloped countries. These differences underlie the different influences of the factors that are key to the modernization of banking services.

According to (Salimon, Mohd Mokhtar, \& Yusr, 2020), in developing countries of Africa evidence indicates that the rate of adoption of E-Banking is still very low despite huge investments made by retail banking institutions to institute E-Banking platforms. Thus, during this development process it is expected that the developing countries will face many unexpected and complex factors that inhibit the speed and scale of E-Banking adoption (Kurnia et al., 2010).

There are certain issues that are considered as major challenges of E-Banking adoption. During the last years a number of studies presented these issues from the perspective of both customers and banks, (Daniela et al., 2010) illustrated these challenges in traditional structures that are unable to respond to the agility required for the E-Banking; resistance from the employees ; legacy systems; security issues; project management problems.

While, (Abbad, Juma'h, \& Abbad, 2012; Havasi, Meshkany, \& Hashemi, 2013) showed that the main challenges to adopt E-Banking are diversity of online banking services, and their relative ease of use, the level of education of customers, as well as their perceptions of the level of risk and the volume of costs.

(Tipi, Xiao, Sukunar, \& Edgar, 2017) have revealed a disappointing level of the adoption and the knowledge of E-Banking in Shandong Province, where there were three reasons hindering consumers: difficult to operate, unnecessary to use, and worry about the security.

While (Mousa, Mousa, Aljshamee, \& Nasir, 2021), arrived that the biggest challenges of the implementation process come from the lack of knowledge and unwillingness of customers as well as the under-developed infrastructure level. This work was partially supported by (Kurnia et al., 2010), who identified that 
the most barriers to E-Banking are related to the environmental context specifically those related to infrastructure, legal framework and cultural attributes that lead to reluctance of customers to use E-Banking.

While (Adewuyi, 2011; Chafjiri \& Mahmoudabadi, 2018; Katiyar, 2018; Khan, Olanrewaju, \& Anwar, 2018; Sudharsan, 2019) found that major problem faced by the respondent while availing the E-Banking services is the security issue. However, (Lusaya \& Kalumba, 2018; Masoud \& AbuTaqa, 2017) concluded that as much as other theories emphasis on the concern for security, security is not a challenge in the adoption and use of E-Banking. The only challenges to the use of E-Banking are availability of information, education level and the cost of the service. This work was supported by (John \& Roitimi, 2014) that although E-Banking is full of Insecurities, it is mostly used by the people of Nigeria due to its convenience, flexibility, speed, efficiency and accessibility of transaction.

(Skvarciany \& Jurevičiene, 2018) argue that the factor that is necessary for trust building in all the examined countries differs: (In Lithuania information and the bank, in Latvia the website and in Estonia the bank). According to the experts, the most powerful factor in the trust-building process in Lithuania and Latvia is the E-Banking system while in Estonia, the website.

Based on the findings from the study of (Adadevoh, 2018), it can adoption of e-commerce by banks in Ghana is influenced by factors such as technology readiness, perceived benefit and organizational commitment. The study also established that the main challenge to ecommerce adoption among banks is the cost factor of ICT, network and software.

Undoubtedly, Managers of the banking sector have a vague picture when it comes to the understanding of the real factors that impact the adoption of e-services provided by various Jordanian banks (Yaseen \& El Qirem, 2018). According to (Abukhzam \& Lee, 2010), it was also discovered that there is currently limited empirical research on identifying the potential elements (inhibitors and drivers) affecting ICT adoption at the organizational level in Arabic countries, particularly Libya. Therefore, (Bouthahab \& Geador, 2014; Hossen, 2014), suggests Banks in Libya have to develop a sound strategy before applying mobile banking in order to compete in the global market place. Where, These processes require extensive and comprehensive study of online banking related factors in order to achieve customers' trust and acceptance in online banking technology (Mohamed, 2013).

Therefore, through literature it is clear that there is no agreement about the Barriers to application of electronic banking and there is not enough evidence of consumer acceptance and their stance towards the use of the services. For the purposes of the study, the author divided the Barriers that prevent to adoption the electronic of electronic banking into three main sections as follows:

\subsection{Regulatory Barriers}

An understanding of the factors affecting on adoption the E-Banking services is 
essential both for economists studying the determinants of growth and for the creators and producers of such technologies (Sudharsan, 2019).

Although that internet banking certainly benefits the customers as well as the banks, there are many areas that can be improved in order to make customers adopt this service.

According to (Das \& Khuntia, 2018; Titu \& Rahman, 2013), insufficient legal and regulatory support act as a barrier to online banking, where (Ezeoha, 2005) argues that meaningful advances in this field of banking will be difficult to achieve without comprehensive regulation and improved access to information infrastructure, and that the Internet banking environment will be very complex amidst regulatory deficiencies.

In addition, (Khattab, Ahmed, \& Al-Magli, 2020) suggests that manager perhaps need to make decisions on the need to re-shuffle employees to other departments to execute other activities that support the stream of E-Banking services, where bank's management needs to embrace a fundamentally different paradigm in managing E-Banking channels and in building the capacity of their staff to support the development of these channels. Moreover, research is needed to further investigate more deeply the impact of these channels on employees performance and ultimately on banks performance.

Therefore, (Azouzi, 2009; Isibor et al., 2018; Yaseen \& El Qirem, 2018) recommended the need to Bank's managers segment the market on the basis of age group and take their opinion and will provide them necessary guidance regarding use of online banking, It is worthy to mention that the fear of loss because of transactions errors or hackers plays a significant role in alienating Tunisian customers from online banking. Moreover, (Sleimi, Karam, \& Qubbaj, 2018) top level managers at Arab banks should concentrate on the Responsiveness factor in order to put all bank potential into costumer's satisfaction they should focus on employees' behavioural, employees' motivation.

Furthermore, (Kitigin, Korir, \& Chepkwony, 2021) argue that the government and policymakers should formulate regulatory requirements to make entrepreneurs switch from cash to E-Banking technology. This will change the entrepreneurs' mindset to see technology adoption as a positive move towards enterprise performance. The study also recommends that service providers of E-Banking technology should put measures to ensure that they safeguard, enhance, and introduce online financial support systems that are appropriate to support the customers.

Despite that poor regulation of the e banking structures is a limitation of banking in Nigeria, Where some banks have lost customers due to poor implementation of E-Banking (John \& Roitimi, 2014). However, (Adepoju \& Adeniji, 2020) the study investigated the acceptance of electronic banking system and satisfaction of the staff of Federal Medical Centre, Owo, Ondo State, Nigeria. Thus, based on the preceding discussion the study hypothesize the following:

HO1: There is no significant difference at $(a \geq 0.05)$ among respondents there 
are Regulatory Barriers limiting of adoption the E-Banking in the Libyan commercial banks.

\subsection{Electronic Barriers}

According to (Odhiambo \& Ngaba, 2019) the existing technological and social infrastructure of an individual E-Banking involves the acquisition of a set of devices of complementary technologies, proficiency with internet, familiarity with technological devices such as computers, laptops, tablets and mobile devices and engaging with electronic aided communication and transactions.

The accessibility of the speedy, steady, and reliable internet has an effect on the adoption of the internet banking. If an area has a good intent connectivity, the users are more inclined to use the services of online banking. On the contrary if an area has a poor accessibility to the internet the customers would prefer not to use the online services of banking and instead visit the bank physically (Abdulhadi \& Ahmad, 2021). Several studies have proven that the ease of using the electronic banking system contributes positively to encouraging customers to accept dealing with banks that adopt electronic banking (Echchabi, 2018; Fahmi \& Rohman, 2018; Madavan \& Vethirajan, 2020; Oni \& Ayo, 2010; Poon, 2008; Rahi et al., 2017; Riyadh et al., 2020; Salimon, Mohd Mokhtar, Yusoff, Adeleke, \& Morakinyo, 2017).

Moreover, (John \& Roitimi, 2014) infrastructural deficiency is a major constraint to internet banking in Nigeria, where study further revealed that power cuts during transaction send wrong signals about E-Banking. This work was partially supported by (Teka, 2017).

Furthermore (Firdous \& Farooqi, 2017; Hamadi, 2010; Masoud \& AbuTaqa, 2017; Ramesh, Jaunky, Roopchund, \& Oodit, 2020) identify the "service quality" has significant rapport on e-customer satisfaction and e-loyalty. Among all, reliability, ease of use, secured transaction are the sturdiest dimensions of quality of E-Banking services. In addition, (Parasuraman, Zeithaml, \& Berry, 1985) pointed out that the service quality in E-Banking is largely determined by web elements and in order to provide a good quality of service. Therefore, banks which offer electronic services should provide customers with effective web tools in a suitability presented environment. This was consistent with (Nustini \& Fadhillah, 2020; Shahabi \& Razi, 2019). While (Bashir, Ali, Wai, Hossain, \& Rahaman, 2020), argue that there is no evidence that shows the perceived value role as a mediator for the analysis of customer satisfaction and service quality in Bangladesh. Meanwhile, (Rahman, Saha, Sarker, Sultana, \& Prodhan, 2017) argue that Customers who were habituated with E-Banking in Bangladesh thinks that E-Banking services were relatively good than manual system, but they are not satisfied with the quality of services and bank personnel behavior to that extent, Moreover people were not satisfied about infrastructure development of E-Banking. While, (Ali, 2017) argues that customer service quality can be impacted by E-Banking orientation in Saudi Arabian e-banks. 
Meanwhile, (Khattab et al., 2020) showed the use of E-Banking channels has changed the routine and traditional way of conducting banking activities. It has brought many benefits to banks mainly improving customer satisfaction, however at the same time employees experience challenges when dealing with E-Banking channels such as poor infrastructure, lack of technology upgrade and the lack of technical skills to manage these channels.

According to (Uppal \& Bala, 2017), while using various E-Banking services in India, ATM machine out of cash, Machine out of order, Lack of security \& privacy, complicated process to use, High interest rate service charge for using credit card are the major issues faced by respondents.

Furthermore, (Hammoud et al., 2018) In Lebanon, E-Banking is still mostly limited to the Internet and mobile telephones, This is due in part to slow development of IT infrastructure in the country.

Study of (Adepoju \& Adeniji, 2020) correspondingly examined the factors, which influenced the consumers' level of satisfaction with electronic banking platforms. The research framework developed was based on the indicators of Network Service. This factor has some level of contribution to the consumer's level of satisfaction with electronic banking systems.

However, (Shankar \& Jebarajakirthy, 2019) found contrary to our prediction, website design did not have significant effects on loyalty to E-Banking. Customers use E-Banking for ease of transactions and convenience. They are less concerned with website aesthetics and more so with reliability, privacy and security. The results also indicated that customer service and support had no significant effects on E-Banking loyalty. This might be because E-Banking is now widely used by banking customers and only a minority tend to face difficulties in using E-Banking services.

In Libya, (Elgahwash, 2013) argues that There are numerous factors that need to be overcome for the Libyan banking sector to achieve global competitiveness in the use of self-service ICTs. Therefore, Libya must reach out to its citizens about Internet technology and mobile technology, improve its national technological infrastructure, and include the input of all customers in the implementation of ICT applications and services. Based on this, the following hypothec is formulated:

HO2: There is no significant difference at $(a \geq 0.05)$ among respondents there are Electronic Barriers limiting of adoption the E-Banking in the Libyan commercial banks.

\subsection{Cultural Barriers}

Culture of consumers also determines the propensity to E-Banking as certain cultures tend to be more attached to electronic banking (Haider, Rahim, \& Aslam, 2019; Inegbedion et al., 2019).

Social influence can affect the use of E-Banking because with the many people who use E-Banking, then it can affect other people's thoughts that E-Banking 
can be easy to use and can help work (Adepoju \& Adeniji, 2020; Nayanajith \& Damunupola, 2019; Nustini \& Fadhillah, 2020).

Commission on public perceptions in September, 2003 says that lack of trust has been frequently cited to be one of the key factors that discourage customers from participating in e-commerce, while cultural differences affect the formation of trust. Apart from trust, (Mathiyarasan \& Chitra, 2019) argue that there are other variables which influence the usage of Internet banking. They are intention, beliefs, and subjective norms, trust in the bank, attitude, perceived usefulness and perceived ease of use, where, satisfaction and awareness of customers about the banks are the important aspects.

According to (Sahoo \& Pati, 2020; Teka, 2017), it has been found that very few customers are there who are aware regarding usage of ICT for availing banking services The reason is lack of awareness and fear among customers. This was confirmed by (Boshkoska \& Sotiroski, 2018; Daniela et al., 2010; Stavins, 2001) have shown that with the increase of qualified and educational level of customers the satisfaction and approval to get such E-Banking service is also increased. Moreover, (Katiyar, 2018) illiteracy towards online banking are the most significant barriers to Indian online banking sectors. However, (Teka \& Sharma, 2017) argue that customers' E-Banking usage behavior is untouched to the educational level. (Sainath Malisetty, 2018), suggests that, For Educating the customer Regulatory prerequisites and operational changes at times require modifications in the traditional methods to operate business. Mobile messengers can be a viable channel to interact with and educate customers on these progressions. Where Customers can likewise find out about new product launches through mobile messengers and rapidly bring up concerns and questions about them.

On the other hand, (Adepoju \& Adeniji, 2020; Nasri \& Zarai, 2014) clarified that customer' intention to use Electronic banking can be affected by perceived usefulness and perceived ease of use. Likewise, (Bouthahab \& Geador, 2014) Libyan customer knowledge is necessary for adopting mobile banking to know customer intention to use mobile banking and able to use a new technology.

According to (Ya-Lan, 2018) Compared with developed countries China's E-Banking business is still in the development stage, many banks are relatively extensive in marketing management and marketing methods are relatively backward. The bank's marketing in electronic banking has exposed several shortcomings. For example, the bank's front-line staff's understanding of electronic banking business is not deep.

Based on (Adholiya \& Adholiya, 2019) as the banking activities and its users are considered as the most vulnerable profile for the cyber attack and malpractices because of lack of knowledge awareness and acquaintance for the secure and confidential cyber practices. Having this in mind, it is theoretically clear that consumers of E-Banking who are skeptic in nature would feel reluctant to trade-in or engage in a successful online transaction taking into consideration perceived identity theft associated with E-Banking. At the same time, the confi- 
dence, integrity, and privacy concern they (users) hold for the technology is at stake (Jibril, Kwarteng, Chovancova, \& Denanyoh, 2020). Accordingly, the following hypothec are proposed:

HO3: There is no significant difference at $(a \geq 0.05)$ among respondents there Cultural Barriers limiting of adoption the E-Banking in the Libyan commercial banks.

According to (Mathiyarasan \& Chitra, 2019), it shows that the customers of private sector banks are of higher level than that of the public sector. This work was supported by (Rajendran \& Balathandayutham, 2020) where The result of the study shows that customers of Public Sector Banks have lesser perception of the various dimensions of e-service quality compared with the private sector Banks. Nevertheless, (Priyanga, 2020) suggests the private sector banks need to improve the level of transparency and also the level of safety and security of online transactions since some of the customers are skeptical about the level of confidentiality of their transactions.

Moreover, (Singhal, 2017), urban customers are aware about E-Banking they utilize it also and they find private banks' website more user friendly than public banks, But they are not satisfied with the high charges charged by private banks to provide E-Banking facility. Therefore, (Priyanga, 2020) suggests should be made available internet banking facility in all rural branches to cover up the rural areas with ATMs, mobile and telebanking, so that the people in rural areas can also avail better services.

(Adholiya \& Adholiya, 2019), argue that public and private sector bank customers of Udaipur district are well-exposed to cyber threats and security issues and challenges and about their level of awareness for the common cyber attacks and threats in electronic banking is good for attacks through mass media.

According to (Kavitha, 2017), there isn't any comparison study between the public and private sector banks to adoption the e banking, Moreover, suggested that studies can be conducted focusing on that. The following hypothec are proposed:

HO4: There are no significant differences at $(a \geq 0.05)$ among respondents to adopt the E-Banking in the Libyan commercial banks due to the bank's ownership (public-private).

\section{Problem Statement}

Despite, E-Banking was adopted by banks so as to improve their service delivery, decongest queues in the banking hall, enable customers to withdraw cash 24/7, aid international payment and remittance, track personal banking transaction, request for online statement, or even transfer deposit to a third party account (John \& Roitimi, 2014). Despite, the planning of strategies of the Libyan Central Bank has expressed its intention for upgrading to modern technologies, $(\mathrm{Gu}$, Lee, \& Suh, 2009), in addition that Libyan customers have accepted the new technology and they are ready to use it, irrespective of ages and occupation 
(Bouthahab \& Geador, 2014). Where, Libyan bank customers perceive Internet banking to be risky but essential to development and growth of the economy (Hossen, 2014). Furthermore, (Abukhzam \& Lee, 2010) Libyan banks Despite its recent recognition of the advantages of e technology in boosting banking services, the company has yet to incorporate and integrate this innovation into its banking delivery plan. Instead, they continue to use traditional banking delivery methods, such as paper-based branch networks, to supply the majority of their banking products and services. This is mainly due to bank employees' aversion to new banking technologies, which led to a problem in the Libyan economy (Ullah et al., 2013). Therefore, the 2013-2014 liquidity crisis in Libya has resulted in many Libyans' difficulties accessing their banking accounts and managing their financial standing, Such destroyed community confidence in the banking sectors and trust in local banks has diminished. So, many commercial banks have developed new mobile payment techniques particularly the "Mobi Cash" Service offered by Wahda Bank to assist Libyan customers in accessing their accounts and carrying out their financial transactions (Bouthahab \& Khaled, 2021; Ramali, 2018).

Undoubtedly, the developing countries like Libya Suffering from low level of ICT infrastructure (Elgahwash, 2013). Where, (Alnaas \& Geebren, 2017; Ullah et al., 2013) recommended banks in Libya need to improve quality of services by focusing on improving quality of banking services. Therefore, (Abukhzam \& Lee, 2010) Libya's economic restructuring necessitates the adoption of E-Banking services.

Thus, understanding the reasons for this resistance would be useful for bank managers in Libya formulating strategies aimed at increasing online banking use. Accordingly, the study problem can be formulated in the following main question:

- What are the barriers to adoption E-Banking in Libyan commercial banks?

\section{Objectives of the Study}

The main objective of the study was to investigate the Barriers that hinder adopting the E-Banking in Libyan commercial banks. Through The specific objectives of this study were:

1) Detecting the Regulatory Barriers that hinder adoption of the E-Banking in Libyan Banks.

2) Detecting the Electronic Barriers that hinder adoption of the E-Banking in Libyan Banks.

3) Detecting the Cultural Barriers that hinders adoption of the E-Banking in Libyan Banks.

4) Detecting the differences between the respondents about Barriers that hinder adoption of E-Banking in Libyan Banks due to the bank's ownership (public-private). 


\section{Contribution of the Study}

This study derives its importance from the following:

1) Knowing the Barriers that limit the adoption of electronic banking gives an indication to the decision-makers of Libyan commercial banks about the Regulatory, Electronic and Cultural weaknesses which allows the management of banks to evaluate the banking system and take appropriate strategies.

2) Reaching results on the Barriers that limit the adoption of electronic banking in Libyan commercial banks help those interested in identifying the reality of the banking process in Libya in light of the competition in the global banking environment.

3) The author hopes that this study will contribute to enriching scientific research in Libya in the field of electronic banking as this study is (according to the researcher's knowledge) the first that deals with the study of the Regulatory, Electronic and Cultural Barriers that limit the adoption of electronic banking in Libyan commercial banks.

\section{Methodology}

Primary data are collected by means of a structured questionnaire. Secondary data are collected from various journals, books, annual reports of the bank, and internets.

The descriptive analytical approach was used because this approach is appropriate in this type of studies, and through the Statistical Package for Social Sciences (IBM SPSS 19) program, the following statistical methods were used to achieve the objectives of the study:

1) Descriptive statistics methods represented in the arithmetic mean and standard deviation to describe the study variables.

2) Normality Distribution Test.

3) Cronbach's Alpha Test.

4) One simple t-test was used to identify the most significant barriers to electronic banking adoption at Libyan commercial banks.

5) Independent-sample t-test identifies the extent to which there are statistically significant differences in the respondents opinions about the Barriers to adoption the Electronic Banking in Libyan commercial banks due to the bank's ownership (public-private).

\subsection{Research Instrument}

This study used self-administered questionnaires covering all the variables in the study. The questionnaire was divided into three parts: the first, about the Regulatory Barriers (9 questions); the second, Electronic Barriers (9 questions), and the third, Cultural Barriers ( 9 questions), in a total of 27 questions. A five point Likert scale was used to ease data processing and analysis. The scale was marked 1 - 5 where; 1 representing strongly "disagree" and 5 strongly "agree". And the basis of the average review of the answers by the numerical average of $3(\mu=3)$. 


\subsection{Study Community and Sample}

The present study takes up all banks at Tobruk city. Three Banks from private sector: (Bank of Commerce \& Development, Arab consensus Bank, and Aman Bank) and four Banks from public sector (Al Wahda Bank, National Commercial Bank, Jumhouria Bank, and North Africa Bank).

The sampling procedure used was the non-probabilistic, Sample of study represented by those in charge of managing commercial banks operating in the city of Tobruk, they are (The bank manager-deputy director-assistant manager the head of current accounts department-, the head of cash department and the head of credit), because they are the decision-makers in the bank and more understand of work environment. Where, the results of the study can be generalized to all Libyan banks, because the banks in Libya have the similar characteristics, and follows the same policies.

Where 22 questionnaire forms were distributed, all valid for analysis, and $\mathrm{Ta}$ ble 1 shows the names of the banks to which the forms were distributed and the ownership of each bank.

It is observed from Table 1 shows that the total number of questionnaire forms were used are 22, 15 forms were distributed to the public sector, while 7 they were distributed to the private sector.

\section{Results and Discussion}

\subsection{Normality Distribution Test}

In this study, Kolmogorov-Smirnova, and Shapiro-Wilk tests were used for assessing normality, and all variables were found to meet with the normality requirements, as shown in Table 2.

\subsection{Validity and Stability of the Tool}

Cronbach's Alpha test was used to test the validity and reliability of the questionnaire items, in Table 3 results are shown.

Table 1. The names and ownership of banks.

\begin{tabular}{cccc}
\hline \multirow{2}{*}{ Name of Bank } & Type of Bank & \multicolumn{2}{c}{ NO. OF RESPONDENTS } \\
\cline { 3 - 4 } & & Nos. & $(\%)$ \\
\hline Al Wahda Bank & Public & 4 & $18 \%$ \\
National Commercial Bank & Public & 3 & $14 \%$ \\
North Africa Bank & Public & 3 & $14 \%$ \\
Jumhouria Bank & Public & 5 & $23 \%$ \\
Bank of Commerce \& Development & Private & 4 & $18 \%$ \\
Arab consensus Bank & Private & 2 & $9 \%$ \\
Aman Bank & Private & 1 & $4 \%$ \\
Total & & 22 & $100 \%$ \\
\hline
\end{tabular}


Table 2. Tests of normality.

\begin{tabular}{ccccccc}
\hline & \multicolumn{3}{c}{ Kolmogorov-Smirnova } & \multicolumn{3}{c}{ Shapiro-Wilk } \\
\cline { 2 - 7 } & Statistic & df & Sig. & Statistic & df & Sig. \\
\hline Regulatory Barriers & 0.112 & 21 & $0.200^{\star}$ & 0.956 & 22 & 0.417 \\
Electronic Barriers & 0.182 & 21 & 0.055 & 0.873 & 22 & 0.009 \\
Cultural Barriers & 0.197 & 21 & 0.027 & 0.848 & 22 & 0.003 \\
\hline
\end{tabular}

Table 3. Reliability test result.

\begin{tabular}{ccc}
\hline Variables & Number of items & Cronbach's Alpha \\
\hline Regulatory Barriers & 9 & 0.857 \\
Electronic Barriers & 9 & 0.714 \\
Cultural Barriers & 9 & 0.769 \\
Overall & 27 & 0.791 \\
\hline
\end{tabular}

Previous table shows that the value of the Cronbach's Alpha coefficient (0.791), likewise for all variables. Which is an acceptable percentage for the purposes of scientific research, exceeds the statistically acceptable percentage of (0.6), (Maiyaki \& Mohd Mokhtar, 2011), which means if the questionnaire is distributed on another sample at different times, there is a probability of $(79.1 \%)$ that the same results will be obtained.

\subsection{Hypothesis Testing}

One-Sample T-test and Independent Sample T-test were used for hypothesis testing as following:

HO1: There is no significant difference at $(a \geq 0.05)$ among respondents there are Regulatory Barriers limiting of adoption the E-Banking in the Libyan commercial banks.

Table 4 shows the results of One Sample T-test, about Regulatory Barriers.

The details provided in Table 4 show The One-Sample T-test that $(P$ value $=$ 0.000 ) which was less than 0.05 , hence the result was significant at $5 \%$ level of significance. It means there were Regulatory Barriers that hinder of adoption the E-Banking service in E-Banking in the Libyan commercial banks. Therefore, the first null hypothesis is rejected.

Where the results showed that all items were statistically significant, and they represent the regulatory Barriers that limit of adoption the electronic banking in Libyan commercial banks. Where, The Bureaucratic procedures that hinder the speed of implementation of electronic transactions comes at the forefront of Regulatory Barriers in with mean of 4.5000, then The weak role of banks in raising customer awareness about electronic services with mean of 4.3636, then Weak effective leadership with mean of 4.0455, This was consistent with (Daniela et al., 2010) thus, all other Regulatory Barriers, as shown in the previous table. 
Table 4. Results of one-sample t-test statistics about regulatory barriers.

\begin{tabular}{|c|c|c|c|c|c|}
\hline No & Regulatory Barriers & Mean & Std. Deviation & $\mathbf{t}$ & $P$ value at $5 \%$ \\
\hline & Total & 3.747 & 0.763 & 23.036 & 0.000 \\
\hline 1 & $\begin{array}{l}\text { Weak efficiency of those in charge of providing electronic services to } \\
\text { customers }\end{array}$ & 2.7273 & 1.45346 & 8.801 & 0.000 \\
\hline 2 & $\begin{array}{l}\text { Resistance to change due to fear of additional responsibilities for bank } \\
\text { employees }\end{array}$ & 3.2727 & 1.16217 & 13.208 & 0.000 \\
\hline 3 & $\begin{array}{l}\text { Workers fear losing their jobs due to the expansion of electronic } \\
\text { banking }\end{array}$ & 3.7273 & 1.07711 & 16.231 & 0.000 \\
\hline 4 & $\begin{array}{l}\text { Workers' fear of losing the relationship with customers by using } \\
\text { electronic banking instead of face-to-face treatment }\end{array}$ & 3.3182 & 0.99457 & 15.649 & 0.000 \\
\hline 5 & $\begin{array}{l}\text { Weak effective leadership that supports the adoption of electronic } \\
\text { banking }\end{array}$ & 4.0455 & 1.13294 & 16.748 & 0.000 \\
\hline 6 & $\begin{array}{l}\text { The weak role of banks in raising customer awareness about electronic } \\
\text { services }\end{array}$ & 4.3636 & 0.90214 & 22.688 & 0.000 \\
\hline 7 & Lack of clarity of legal protection procedures in electronic transactions & 3.9091 & 1.10880 & 16.536 & 0.000 \\
\hline 8 & $\begin{array}{l}\text { The pattern of the organizational structure followed that is not } \\
\text { supportive of the adoption of electronic banking }\end{array}$ & 3.8636 & 1.24577 & 14.547 & 0.000 \\
\hline 9 & $\begin{array}{l}\text { Bureaucratic procedures that hinder the speed of implementation of } \\
\text { electronic transactions }\end{array}$ & 4.5000 & 0.85912 & 24.568 & 0.000 \\
\hline
\end{tabular}

$(\mathrm{df}=21$, Test Value $=3)$

HO2: There is no significant difference at $(a \geq 0.05)$ among respondents there are Electronic Barriers limiting of adoption the E-Banking in the Libyan commercial banks.

Table 5 shows the results of One Sample T-test, about Electronic Barriers.

The details provided in Table 5 show The One-Sample T-test that $(P$ value $=$ 0.000 ) which was less than 0.05 , hence the result was significant at $5 \%$ level of significance. It means there were Electronic Barriers that hinder of adoption the E-Banking service in E-Banking in the Libyan commercial banks. Therefore, the second null hypothesis is rejected.

Where the results showed that all items were statistically significant, and they represent the Electronic Barriers that limit of adoption the electronic banking in Libyan commercial banks. Where, the average of all items was very high, which means that all the Electronic Barriers mentioned in the previous table were significant Barriers for respondents. For example slow internet speed and Difficulty in dealing with electronic programs by bank employees, its mean was 4.8182, This result was partially supported by (Abdulhadi \& Ahmad, 2021), then Difficulty accessing ATM websites with mean 4.7727, This was consistent with (Uppal \& Bala, 2017), then The complexity and difficulty of using electronic banking systems with mean 4.7273 it found contrary to our prediction with (Shankar \& Jebarajakirthy, 2019), thus, all other Electronic. 
Table 5. Results of one-sample t-test statistics about electronic barriers.

\begin{tabular}{rlrrrr}
\hline No & \multicolumn{1}{c}{ Electronic Barriers } & Mean & Std. Deviation & t & $P$ value at 5\% \\
\hline & \multicolumn{1}{c}{ Total } & 4.6566 & 0.34615 & 22.447 & 0.000 \\
\hline 1 & Unavailability of internet services & 4.5455 & 0.73855 & 9.815 & 0.000 \\
2 & Poor infrastructure at the country & 4.6818 & 0.47673 & 16.547 & 0.000 \\
3 & The complexity and difficulty of using electronic banking systems & 4.7273 & 0.45584 & 17.773 & 0.000 \\
4 & slow internet speed & 4.8182 & 0.39477 & 21.602 & 0.000 \\
5 & Continuous stop of ATM machines & 4.5909 & 0.59033 & 12.641 & 0.000 \\
6 & Difficulty accessing ATM websites & 4.7727 & 0.42893 & 19.385 & 0.000 \\
7 & Difficulty in dealing with electronic programs by bank employees & 4.8182 & 0.39477 & 21.602 & 0.000 \\
8 & Customers' concern about the security policy of electronic banking & 4.2273 & 1.19251 & 4.827 & 0.000 \\
9 & Problems related to power outages & 4.7273 & 0.55048 & 14.717 & 0.000 \\
\hline
\end{tabular}

$(\mathrm{df}=21$, Test Value $=3)$

HO3: There is no significant difference at $(a \geq 0.05)$ among respondents there Cultural Barriers limiting of adoption the E-Banking in the Libyan commercial banks.

Table 6 shows the results of One Sample T-test, about Cultural Barriers.

The details provided in Table 6 show The One-Sample T-test that $(P$ value $=$ 0.000 ) which was less than 0.05 , hence the result was significant at $5 \%$ level of significance. It means there were Cultural Barriers that hinder of adoption the E-Banking service in E-Banking in the Libyan commercial banks. Therefore, the fourth null hypothesis is rejected.

Where the results showed that all items were statistically significant, and they represent the Cultural Barriers that limit of adoption the electronic banking in Libyan commercial banks. Where, The Lack of knowledge of dealing with computers among customers comes at the forefront of Cultural Barriers in with mean of 4.9091, This was consistent with most studies reviewed and in line with most theories (Boshkoska \& Sotiroski, 2018; Sahoo \& Pati, 2020; Teka, 2017; Teka \& Sharma, 2017), then The Weak of educational level of the bank's customers with mean of 4.8636, it found contrary to our prediction with (Sainath Malisetty, 2018), then Lack Customers knowledge in internet with mean of 4.6818, Likewise (Daniela et al., 2010), thus, all other Cultural Barriers, as shown in the previous table.

HO4: There are no significant differences at $(a \geq 0.05)$ among respondents to adopt the E-Banking in the Libyan commercial banks due to the bank's ownership (public-private).

Table 7, Table 8 show the results of Independent Sample T-test.

As indicated in Table 7 the mean value for answers of respondents in 
Table 6. Results of one-sample t-test statistics about cultural barriers.

\begin{tabular}{|c|c|c|c|c|c|}
\hline No & Cultural Barriers & Mean & Std. Deviation & $\mathrm{t}$ & $P$ value at $5 \%$ \\
\hline & Total & 4.3636 & 0.58913 & 10.857 & 0.000 \\
\hline 1 & Weak of educational level of the bank's customers & 4.8636 & 0.35125 & 24.886 & 0.000 \\
\hline 2 & Lack of knowledge of dealing with computers among customers & 4.9091 & 0.29424 & 30.432 & 0.000 \\
\hline 3 & Lack Customers knowledge in internet & 4.6818 & 0.56790 & 13.891 & 0.000 \\
\hline 4 & The mental image of electronic banking services in society & 4.3636 & 0.90214 & 7.090 & 0.000 \\
\hline 5 & $\begin{array}{l}\text { Lack of awareness of the importance of using electronic banking } \\
\text { for clients }\end{array}$ & 4.4545 & 0.96250 & 7.088 & 0.000 \\
\hline 6 & Customer distrust in electronic banking & 4.3636 & 1.09307 & 5.851 & 0.000 \\
\hline 7 & Difficulty with the language used on the website & 3.7273 & 1.35161 & 2.524 & 0.020 \\
\hline 8 & Lack of knowledge of dealing with smart phones among customers & 4.0000 & 1.34519 & 3.487 & 0.002 \\
\hline 9 & Customers' concern about giving private information & 3.9091 & 1.34196 & 3.177 & 0.005 \\
\hline
\end{tabular}

$(\mathrm{df}=21$, Test Value $=3)$

Table 7. Group statistics.

\begin{tabular}{ccccc}
\hline Type of Bank & N & Mean & Std. Deviation & Std. Error Mean \\
\hline private & 7 & 4.3386 & 0.31531 & 0.11917 \\
public & 15 & 4.2173 & 0.39566 & 0.10216 \\
\hline
\end{tabular}

Table 8. Results of independent sample t-test.

\begin{tabular}{|c|c|c|c|c|c|c|c|}
\hline & $\begin{array}{r}\text { Leven } \\
\text { Equality }\end{array}$ & $\begin{array}{l}\text { st for } \\
\text { rriances }\end{array}$ & \multicolumn{5}{|c|}{ t-test for Equality of Means } \\
\hline & \multirow[t]{2}{*}{$\mathrm{F}$} & \multirow[t]{2}{*}{ Sig. } & \multirow[t]{2}{*}{$\mathrm{t}$} & \multirow[t]{2}{*}{ df } & \multirow{2}{*}{$\begin{array}{c}\text { Sig. } \\
\text { (2-tailed) }\end{array}$} & \multicolumn{2}{|c|}{$\begin{array}{l}\text { 95\% Confidence Interval } \\
\text { of the Difference }\end{array}$} \\
\hline & & & & & & Lower & Upper \\
\hline Equal variances assumed & 0.199 & 0.660 & 0.710 & 20 & 0.486 & -0.23517 & 0.47785 \\
\hline Equal variances not assumed & & & 0.773 & 14.664 & 0.452 & -0.21390 & 0.45658 \\
\hline
\end{tabular}

Private Banks is 4.3386 and the mean value for answers of respondents in Public Banks 4.2173, which indicates no existence of practical difference between answers of respondents in Private and Public Banks to adoption the E-Banking in the Libyan commercial banks.

As indicated in Table 8 the significance value for Levene's test is 0.660 which is above 0.05 and it proves that the variance for the two groups (private and public) is the same and thereby it shows that the assumption of equality of variance is satisfied. Accordingly (Pallant, 2007) the first row results of independent samples t-test are selected.

The independent sample T-test output is $P$-value $=0.486$, where, that $(P$-value big than 0.05), there is no statistically significant difference between the answers 
of respondents that's there Barriers that limit to application of E-Banking in the Libyan commercial banks due to the bank's ownership (public-private). Therefore, the fourth null hypothesis is rejected.

\section{Conclusion and Recommendations}

The overall goal of this study is to investigate barriers that hinder Libyan commercial banks from adopting E-Banking. By analysis of T-test, the results revealed that there are Regulatory, Electronic and Cultural Barriers that limit the adoption of Electronic Banking in Libyan Commercial Banks. The study also found that there were no differences between the respondents' answers in the presence of these Barriers due to the Ownership of the Bank, where, it was apparent that almost all participants, whether from a Public or Privet Banks, were fully in agreement concerning the Barriers to adoption of the E-Banking.

This study suggests that in order to successfully introduce E-Banking in Libyan commercial banks, the following strategies are recommended:

1) Government should create a congenial environment for this sector, and provide adequate training and technical support to develop the manpower.

2) Banks should have their own strategic plans for E-Banking.

3) E-Banking service must be convenient, uncomplicated, quick, easily available and user friendly.

4) Increase awareness of modern banking technologies among bank staff through various communication channels (e.g. conferences and workshops).

\section{Acknowledgements}

The author would like to thank Mr. Ahmed Geebren, for his help on the construction of the questionnaires. The author also extends his thanks and appreciation to Mr. Faraj Al-Mismari for reviewing the paper linguistically.

\section{Conflicts of Interest}

The author declares no conflicts of interest regarding the publication of this paper.

\section{References}

Abbad, M., Juma'h, M. A., \& Abbad, M. (2012). The Development of E-Banking in Developing Countries in the Middle East. Journal of Finance, Accounting and Manage ment, 3, 107-123.

Abdulhadi, R. A., \& Ahmad, S. (2021). Internet Banking in Saudi Arabia. PalArch's Journal of Archaeology of Egypt/Egyptology, 18, 673-684.

Abukhzam, M., \& Lee, A. (2010). Factors Affecting Bank Staff Attitude towards E-Banking Adoption in Libya. The Electronic Journal of Information Systems in Developing Countries, 42, 1-15. https://doi.org/10.1002/j.1681-4835.2010.tb00298.x

Adadevoh, C. (2018). Factors That Influence the Adoption of E-Commerce in the Ghanaian Banking Industry. International Journal of Innovative Research and Development, 7, 23-27. https://doi.org/10.24940/ijird/2018/v7/i2/FEB18017 
Adepoju, A., \& Adeniji, A. (2020). Technology Acceptance of E-Banking Services in an Unnatural Environment. SEISENSE Journal of Management, 3, 34-50. https://doi.org/10.33215/sjom.v3i3.336

Adewuyi, I. (2011). Electronic Banking in Nigeria: Challenges of the Regulatory Authorities and the Way Forward. International Journal of Economic Development Research and Investment, 2, 149-156.

Adholiya, A., \& Adholiya, S. (2019). A Study on Cyber Security Practices and Tips Awareness among E-Banking Services Users of Udaipur, Rajasthan. International Journal of Scientific Research in Multidisciplinary Studies, 5, 148-154.

Ali, M. S. Y. (2017). The Effect of E-Banking Orientation on Customer Service Quality KSA Banks Customers' Perspective. International Journal of Civil Engineering and Technology, 8, 546-563.

Alnaas, H. M., \& Geebren, A. (2017). Effecting Factors on Decline Liquidity in Libyan Commercial Banks: An Applied Study on Commercial Banks in the City of Tobruk. In Conference of Crisis Management in Libya-Reality and Expectation (pp. 1-16). University of Omar Mukhtar.

Altobishi, T., Erboz, G., \& Podruzsik, S. (2018). E-Banking Effects on Customer Satisfaction: The Survey on Clients in Jordan Banking Sector. International Journal of Marketing Studies, 10, 151-161. https://doi.org/10.5539/ijms.v10n2p151

Arora, S., \& Kaur, S. (2018). Perceived Risk Dimensions and Its Impact on Intention to Use E-Banking Services: A Conceptual Study. Journal of Commerce and Accounting Research, 7, 19-27.

Azouzi, D. (2009). The Adoption of Electronic Banking in Tunisia: An Exploratory Study. Journal of Internet Banking and Commerce, 14, 1-11.

Bashir, M. A., Ali, M. H., Wai, L. M., Hossain, M. I., \& Rahaman, M. S. (2020). Mediating Effect of Customer Perceived Value on the Relationship between Service Quality and Customer Satisfaction of E-Banking in Bangladesh. International Journal of Advanced Science and Technology, 29, 3590-3606.

Boshkoska, M., \& Sotiroski, K. (2018). An Empirical Study of Customer Usage and Satisfaction with E-Banking Services in the Republic of Macedonia. Croatian Review of Economic, Business and Social Statistics, 4, 1-13. https://doi.org/10.2478/crebss-2018-0001

Bouthahab, I. E., \& Geador, B. B. (2014). Mobile Phone Banking Applies and Customer Intention-A Case Study in Libya. International Journal of Social, Education, Economics and Management Engineering, 8, 2052-2057.

Bouthahab, I. E., \& Khaled, M. M. H. (2021). The Mediating Role of Socio-Economy on the Relationship between Customer Lifestyles and the Awareness of MobiCash Banking Services of Wahda Bank in Libya. Journal of Emerging Economies \& Islamic Research, 9, 88-107. https://doi.org/10.24191/jeeir.v9i1.11210

Bouthahab, I., \& Elmansori, E. (2017). Dynamics Impacting Libyan Customers to Adopt Mobile Banking in Libya. International Journal of Research in Business Studies and Management, 4, 8-18.

Chafjiri, M. B., \& Mahmoudabadi, A. (2018). Developing a Conceptual Model for Applying the Principles of Crisis Management for Risk Reduction on Electronic Banking. American Journal of Computer Science and Technology, 1, 31-38. https://doi.org/10.11648/j.ajcst.20180101.15

Chedrawi, C., Harb, B., \& Saleh, M. (2019). The E-Banking and the Adoption of Innovations from the Perspective of the Transactions Cost Theory: Case of the Largest Com- 
mercial Banks in Lebanon. In Y. Baghdadi, \& A. Harfouche (Eds.), ICT for a Better Life and a Better World (Vol. 30, pp. 149-164). Springer.

https://doi.org/10.1007/978-3-030-10737-6 10

Chhaya, B. B., \& Mittal, D. (2021). Assessing the Impact of Service Quality Anticedents on the Use of E-Banking Services' Intentions. Utkal Historical Research Journal, 34, 182-191.

Daka, C., \& Phiri, J. (2019). Factors Driving the Adoption of E-Banking Services Based on the UTAUT Model. International Journal of Business and Management, 14, 43-52. https://doi.org/10.5539/ijbm.v14n6p43

Daniela, B., Simona, M., \& Dragos, P. (2010). Electronic Banking-Advantages for Financial Services Delivery. Annals of Faculty of Economics, 1, 672-677.

Das, K. K., \& Khuntia, C. (2018). A Critical Review of Literature on E-Banking Services of Commercial Banks. Asian Journal of Multidimensional Research (AJMR), 7, 183-195.

Echchabi, A. (2018). E-Banking Acceptance in Thailand: An Emphasis on Islamic Banks' Customers. European Journal of Islamic Finance, No. 9, 1-5.

Economic Commission for Africa (2007, 1 March). African Ministers of Finance, Planning and Economic Development/Fortieth Session of the Commission.

Elgahwash, F. O. S. (2013). The Role of Information and Communication Technologies in Enhancing Customer Relationships in the Libyan Banking Sector. Doctor of Philosophy Doctor of Philosophy, University of Wollongong. http://ro.uow.edu.au/theses/4021

Ezeoha, A. E. (2005). Regulating Internet Banking in Nigeria: Problems and Challenges-Part 1. Journal of Internet Banking and Commerce, 10, 1-5.

Fahmi, S., \& Rohman, F. (2018). Factors Affecting Indonesian Consumers to Switch, Using Mobile Banking and Internet Banking Service. In The International Conference of Organizational Innovation (pp. 1236-1248). Knowledge E.

Firdous, S., \& Farooqi, R. (2017). Impact of Internet Banking Service Quality on Customer Satisfaction. Journal of Internet Banking and Commerce, 22, 1-17.

Gu, J.-C., Lee, S.-C., \& Suh, Y.-H. (2009). Determinants of Behavioral Intention to Mobile Banking. Expert Systems with Applications, 36, 11605-11616.

https://doi.org/10.1016/j.eswa.2009.03.024

Haider, Z., Rahim, A., \& Aslam, F. (2019). Antecedents of Online Banking Adoption in Pakistan: An Empirical Study. International Research Journal of Arts \& Humanities (IRJAH), 47, 197-214.

Hamadi, C. (2010). The Impact of Quality of Online Banking on Customer Commitment. Communications of the IBIMA, 2010, Article ID: 844230 .

https://doi.org/10.5171/2010.844230

Hammoud, J., Bizri, R. M., \& El Baba, I. (2018). The Impact of E-Banking Service Quality on Customer Satisfaction: Evidence from the Lebanese Banking Sector. Sage Open, 8 , 1-12. https://doi.org/10.1177/2158244018790633

Hammouri, Q., Majali, T., Almajali, D., Aloqool, A., \& AlGasawneh, J. A. (2021). Explore the Relationship between Security Mechanisms and Trust in E-Banking: A Systematic Review. Annals of the Romanian Society for Cell Biology, 25, 17083-17093. https://www.annalsofrscb.ro/index.php/journal/article/view/8998

Havasi, F., Meshkany, F. A., \& Hashemi, R. (2013). E-Banking: Status, implementation, Challenges, Opportunities. IOSR Journal of Humanities and Social Science, 12, 40-48.

https://doi.org/10.9790/0837-1264048 
Hossen, G. K. E. (2014). Consumer Perceptions of the barriers to Adoption of Internet Banking: A Case Study in Libya. Doctor of Philosophy Doctor of Philosophy, University of Southern Queensland.

Hu, Y.-C., \& Liao, P.-C. (2011). Finding Critical Criteria of Evaluating Electronic Service Quality of Internet Banking Using Fuzzy Multiple-Criteria Decision Making. Applied Soft Computing, 11, 3764-3770. https://doi.org/10.1016/j.asoc.2011.02.008

Inegbedion, H., Inegbedion, E. E., Osifo, S. J., Eze, S. C., Ayeni, A., \& Akintimehin, O. (2019). Exposure to and Usage of E-Banking Channels: Implications for Bank Customers' Awareness and Attitude to E-Banking in Nigeria. Journal of Science and Technology Policy Management, 11, 133-148. https://doi.org/10.1108/JSTPM-02-2019-0024

Isibor, A. A., Omankhanlen, A., Okoye, L. U., Achugamonu, B. U., Adebayo, M., Afolabi, G., \& Ayodeji, O. (2018). Impact of Electronic Banking Technology on Customers' Satisfaction and Economic Growth in Nigeria. International Journal of Civil Engineering and Technology, 9, 536-544.

http://www.iaeme.com/ijciet/issues.asp?JType=IJCIET\&VType=9\&IType=12

Ismail, L. B., \& Alawamleh, M. (2017). The Impact of Online Banking of Customer Satisfaction in Jordan. Journal of Organisational Studies and Innovation, 4, 1-13.

Jibril, A. B., Kwarteng, M. A., Chovancova, M., \& Denanyoh, R. (2020). Customers' Perception of Cybersecurity Threats toward E-Banking Adoption and Retention: A Conceptual Study. In The ICCWS 2020 15th International Conference on Cyber Warfare and Security (pp. 270-276).

John, O., \& Roitimi, O. (2014). Analysis of Electronic Banking and Customer Satisfaction in Nigeria. European Journal of Business and Social Sciences, 3, 14-27.

Katiyar, R. (2018). A Study of Barriers to E-Banking in the Indian Scenario. In The Fourteenth International Conference on eLearning for Knowledge-Based Society (Ed.), The Fourteenth International Conference on eLearning for Knowledge-Based Society (pp. 17.1-17.8).

Kavitha, S. (2017). Factors Influencing Satisfaction on E-Banking. AIMS International Journal of Management, 11, 103-115. https://doi.org/10.26573/2017.11.2.2

Keskar, M. Y., \& Pandey, N. (2018). Internet Banking: A Review (2002-2016). Journal of Internet Commerce, 17, 310-323. https://doi.org/10.1080/15332861.2018.1451969

Khan, B. U. I., Olanrewaju, R. F., \& Anwar, F. (2018). Rehashing System Security Solutions in E-Banking. International Journal of Engineering \& Technology, 7, 4905-4910.

Khattab, I., Ahmed, A. M., \& Al-Magli, O. A. O. (2020). The Implications of E-Banking Channels on Job Security and Personal Development. Banking \& Financial Studies, No. 35, 9-39.

Kimiagari, S., \& Baei, F. (2021). Promoting E-Banking Actual Usage: Mix of Technology Acceptance Model and Technology-Organisation-Environment Framework. Enterprise Information Systems, 1-57. https://doi.org/10.1080/17517575.2021.1894356

Kitigin, B., Korir, M., \& Chepkwony, K. (2021). E-Banking Technology Characteristics and Performance of Micro and Small Enterprise in Kenya: A Moderated Mediation Model of Adoption and Innovative Behavior. SEISENSE Journal of Management, 4, 13-30. https://doi.org/10.33215/sjom.v4i1.480

Kurnia, S., Peng, F., \& Liu, Y. R. (2010). Understanding the Adoption of Electronic Banking in China. In 2010 43rd Hawaii International Conference on System Sciences (pp. 1-10). IEEE. https://doi.org/10.1109/HICSS.2010.421

Lee, M.-C. (2009). Factors Influencing the Adoption of Internet Banking: An Integration of TAM and TPB with Perceived Risk and Perceived Benefit. Electronic Commerce 
Research and Applications, 8, 130-141. https://doi.org/10.1016/j.elerap.2008.11.006

Lusaya, S., \& Kalumba, B. (2018). The Challenges of Adopting the Use of E-Banking to the Customers: The Case of Kasama District Banking Customers. Scholar Journal of Applied Sciences and Research, 1, 26-31.

Madavan, K., \& Vethirajan, C. (2020). The Impact of Electronic Banking Services on the Public and Private Sector Banks in Puducherry Region. Aegaeum Journal, 8, 1046-1056.

Maiyaki, A. A., \& Mohd Mokhtar, S. S. (2011). Determinants of Customer Behavioural Responses: A Pilot Study. International Business Research, 4, 193-197. https://doi.org/10.5539/ibr.v4n1p193

Masoud, E., \& AbuTaqa, H. (2017). Factors Affecting Customers' Adoption of E-Banking Services in Jordan. Information Resources Management Journal (IRMJ), 30, 44-60. https://doi.org/10.4018/IRMJ.2017040103

Mathiyarasan, M., \& Chitra, V. (2019). A Study on Customer Awareness towards Internet Banking-With Reference to Tumkur District. SAARJ Journal on Banking \& Insurance Research, 8, 17-27. https://doi.org/10.5958/2319-1422.2019.00011.0

Mohamed, A. E. (2013). Improving the Libyan Customers' Trust and Acceptance for Online Banking Technology. Degree of Doctor Degree of Doctor, University of Salford.

Mohammed, N., \& Faleel, J. (2021). Empirical Study on Security in Online Banking in Saudi Arabia. PalArch's Journal of Archaeology of Egypt/Egyptology, 18, 58-67.

Mousa, A. H., Mousa, S. H., Aljshamee, M., \& Nasir, I. S. (2021). Determinants of Customer Acceptance of E-Banking in Iraq Using Technology Acceptance Model. Telkomnika, 19, 421-431. https://doi.org/10.12928/telkomnika.v19i2.16068

Nasri, W., \& Zarai, M. (2014). Empirical Analysis of Internet Banking Adoption in Tunisia. Asian Economic and Financial Review, 4, 1812-1825.

Nayanajith, G., \& Damunupola, K. (2019). Effects of Subjective Norms and Security on Online Banking Adoption: Multilevel Linear Model Analysis. Asian Journal of Multidisciplinary Studies, 2, 9-16.

Nuha, M., Mahmud, S., \& Sattar, A. (2021). A Case Study and Fraud Rate Prediction in E-Banking Systems Using Machine Learning and Data Mining. In S. Borah, R. Pradhan, N. Dey, \& P. Gupta (Eds.), Soft Computing Techniques and Applications (Vol. 1248, 71-83). Springer. https://doi.org/10.1007/978-981-15-7394-1 6

Nustini, Y., \& Fadhillah, N. (2020). Factors that Influence the Use of E-Banking and the Effect on Consumptivism. Review of Integrative Business and Economics Research, 9, 330-345.

Odhiambo, S., \& Ngaba, D. (2019). E-Banking Services and Financial Performance of Commercial Banks in Kenya. International Academic Journal of Economics and Finance, 3, 132-153. http://www.iajournals.org/articles/iajef v3 i4 132 153.pdf

Oni, A. A., \& Ayo, C. K. (2010). An Empirical Investigation of the Level of Users' Acceptance of E-Banking in Nigeria. Journal of Internet Banking and Commerce, 15, 1-13.

Osho, G. S. (2008). How Technology Is Breaking Traditional Barriers in the Banking Industry: Evidence from Financial Management Perspective. European Journal of Economics, Finance and Administrative Sciences, No. 11, 15-21.

Paliwal, N. (2017). E-Banking-Influence, Threats and Security. Journal of Advanced Computing and Communication Technologies, 5, 43-47.

Pallant, J. (2007). Survival Manual. Open University Press.

Parasuraman, A., Zeithaml, V. A., \& Berry, L. L. (1985). A Conceptual Model of Service 
Quality and Its Implications for Future Research. Journal of Marketing, 49, 41-50. https://doi.org/10.1177/002224298504900403

Poon, W. C. (2008). Users' Adoption of E-Banking Services: The Malaysian Perspective. Journal of Business \& Industrial Marketing, 23, 59-69. https://doi.org/10.1108/08858620810841498

Priyanga, P. (2020). E-Banking-Transformational Change in Traditional Banking a Focus on Customer Perception towards Select Public and Private Banks in Nagapattinam District. EPRA International Journal of Multidisciplinary Research (IJMR), 6, 484-192.

Rahi, S., Ghani, M., \& Alnaser, F. (2017). Predicting Customer's Intentions to Use Internet Banking: The Role of Technology Acceptance Model (TAM) in E-Banking. Management Science Letters, 7, 513-524. https://doi.org/10.5267/j.msl.2017.8.004

Rahman, M., Saha, N. K., Sarker, M. N. I., Sultana, A., \& Prodhan, A. (2017). Problems and Prospects of Electronic Banking in Bangladesh: A Case Study on Dutch-Bangla Bank Limited. American Journal of Operations Management and Information Systems, 2, 42-53.

Rajendran, D. S., \& Balathandayutham, P. (2020). Customer Satisfaction on E-Banking Services of Public and Private Sector Banks in Puducherry Region-An Empirical Analysis. International Journal of Management, 11, 1247-1262.

Rajguru, M. P. P. (2014). E-Banking in India: Challenges and Opportunities. Research Dimensions, 4, 14-19.

Ramali, K. (2018). Digital Payment Methods in Libya. https://medium.com/@k libya/digital-money-libya-11883c69242e

Ramesh, V., Jaunky, V. C., Roopchund, R., \& Oodit, H. S. (2020). “Customer Satisfaction", Loyalty and "Adoption" of E-Banking Technology in Mauritius. In V. Bhateja, S. Satapathy, \& H. Satori (Eds.), Embedded Systems and Artificial Intelligence (Vol. 1171, pp. 861-873). Springer. https://doi.org/10.1007/978-981-15-0947-6 82

Riyadh, H. A., Tahar, A., Indrasari, A., Alfaiza, S. A., Sultan, A., Abusharbeh, M., \& Alhaleh, S. (2020). A Comparative Analysis of E-Banking Usage and Technology Acceptance in Iraqi and Indonesian Banks. Test Engineering and Management, 83, 5799-5808.

Safeena, R., Date, H., \& Kammani, A. (2011). Internet Banking Adoption in an Emerging Economy: Indian Consumer's Perspective. International Arab Journal of e-Technology, 2, 56-64.

Sahoo, A. P., \& Pati, G. (2020). A Study on Individuals Behavior towards E-Banking and M-Banking in Bhubaneswar City. A Global Journal of Social Sciences, 3, 35-38.

Sainath Malisetty, A. R. (2018). Next Generation E-Banking through Mobile Messengers. Indian Journal of Public Health Research \& Development, 9, 31-34.

https://doi.org/10.5958/0976-5506.2018.00086.4

Salimon, M. G., Mohd Mokhtar, S. S., \& Yusr, M. M. (2020). E-Banking as a Financial Supply Chain System: Can E-TAM Improve Trust and the Rate of Adoption? International Journal of Supply Chain Management (IJSCM), 9, 216-226.

Salimon, M. G., Mohd Mokhtar, S. S., Yusoff, R. Z., Adeleke, A., \& Morakinyo, S. (2017). Facilitating Conditions and Perceived Security as Antecedents of Trust among E-Banking Customers in Nigeria. In 4th Conference on Business Management. Perpustakaan Sultanah Bahiyah, UUM.

Shahabi, V., \& Razi, F. F. (2019). Modeling the Effect of Electronic Banking Expansion on Profitability Using Neural Networks and System Dynamics Approach. Qualitative Research in Financial Markets, 11, 197-210. https://doi.org/10.1108/QRFM-11-2018-0117 
Shankar, A., \& Jebarajakirthy, C. (2019). The Influence of E-Banking Service Quality on Customer Loyalty: A Moderated Mediation Approach. International Journal of Bank Marketing, 37, 1119-1142. https://doi.org/10.1108/IJBM-03-2018-0063

Singhal, S. (2017). Demonetisation and E-Banking in India. Education, 3, 20-25.

Skvarciany, V., \& Jurevičienė, D. (2018). Factors Influencing Individual Customers Trust in Internet Banking: Case of Baltic States. Sustainability, 10, Article 4809. https://doi.org/10.3390/su10124809

Sleimi, M. T., Karam, A. A., \& Qubbaj, I. S. (2018). The Impact of E-Banking Services Quality on Customers Satisfaction Moderated by Customer Trust: Survey on Arab Bank in Amman, Jordan. Journal of Al-Quds Open University for Administrative \& Economic Research, 3, 24-36. https://doi.org/10.33977/1760-003-009-016

Stavins, J. (2001). Effect of Consumer Characteristics on the Use of Payment Instruments. New England Economic Review, No. 3, 19-31.

Sudharsan, S. (2019). Consumer Satisfaction in the E-Banking Sector. International Educational Applied Research Journal (IEARJ), 3, 1-4.

Teka, B. M. (2017). Assessment of the Practices and Challenges of Electronic Banking Adoption in Ethiopia. International Journal of Research in IT and Management, 7, 82-94.

Teka, B. M., \& Sharma, D. (2017). Influence of Demographic Factors on Users' Adoption of Electronic Banking in Ethiopia. Journal of Internet Banking and Commerce, 22, $1-17$.

Tiong, W. N. (2020). Factors Influencing Behavioural Intention towards Adoption of Digital Banking Services in Malaysia. International Journal of Asian Social Science, 10, 450-457. https://doi.org/10.18488/journal.1.2020.108.450.457

Tipi, L., Xiao, Y., Sukunar, A., \& Edgar, D. (2017). Factors Influencing People’s Intention to Adopt E-Banking: An Empirical Study of Consumers in Shandong Province, China. Asian Journal of Computer and Information Systems, 5, 26-43.

Titu, M. A. S., \& Rahman, M. A. (2013). Online Banking System-Its Application in Some Selected Private Commercial Banks in Bangladesh. Journal of Business and Management (IOSR-JBM), 9, 37-44. https://doi.org/10.9790/487X-0943744

Ullah, R., Kamal, Y., \& Ghani, U. (2013). Quality Evaluation of Banking Services for Development of E-Banking in Libya. African Journal of Business Management, 7, 701-712.

Uppal, R. K., \& Bala, R. (2017). A Study of Awareness and Usage Level of Customers towards E-Banking Services in Semi-Urban Area of Mansa District. AGU International Journal of Research in Social Sciences \& Humanities, No. 5, 523-532.

Yaseen, S. G., \& El Qirem, I. A. (2018). Intention to Use E-Banking Services in the Jordanian Commercial Banks. International Journal of Bank Marketing, 36, 557-571. https://doi.org/10.1108/IJBM-05-2017-0082

Yuan, Y.-L. (2018). Analysis on the Development of Electronic Banking Business of Commercial Banks in China. In 2018 International Conference on E-commerce and Contemporary Economic Development (ECED 2018) (pp. 153-156).

Zyberi, I. (2021). The Impact of Personal Factors on Trust and Image of E-Banking Customers. Research and Innovation, 106-114. 